\title{
Article \\ Green Synthesis of Silver Nanoparticles Using Olea europaea Leaf Extract for Their Enhanced Antibacterial, Antioxidant, Cytotoxic and Biocompatibility Applications
}

\author{
Hanen Sellami ${ }^{1} \mathbb{D}$, Shakeel Ahmad Khan ${ }^{2, *} \mathbb{D}$, Ishaq Ahmad ${ }^{3}$, Abdullah A. Alarfaj ${ }^{4}$, Abdurahman H. Hirad ${ }^{4}$ \\ and Ahmed E. Al-Sabri ${ }^{4}$ \\ 1 Laboratory of Treatment and Valorization of Water Rejects, Water Research and Technologies Center (CERTE), \\ Borj-Cedria Technopark, University of Carthage, Soliman 8020, Tunisia; sellami_hanen@yahoo.fr \\ 2 Center of Super-Diamond and Advanced Films (COSDAF), Department of Chemistry, City University of \\ Hong Kong, 83 Tat Chee Avenue, Kowloon, Hong Kong 999077, China \\ 3 Department of Physics, The University of Hong Kong, Hong Kong 999077, China; ahmadrai@hku.hk \\ 4 Department of Botany and Microbiology, College of Science, King Saud University, P.O. Box 2455, \\ Riyadh 11451, Saudi Arabia; aalarfajj@ksu.edu.sa (A.A.A.); ahirad@ksu.edu.sa (A.H.H.); \\ aalsabri@ksu.edu.sa (A.E.A.-S.) \\ * Correspondence: shakilahmadkhan56@gmail.com
}

Citation: Sellami, H.; Khan, S.A.; Ahmad, I.; Alarfaj, A.A.; Hirad, A.H.; Al-Sabri, A.E. Green Synthesis of Silver Nanoparticles Using Olea europaea Leaf Extract for Their Enhanced Antibacterial, Antioxidant, Cytotoxic and Biocompatibility Applications. Int. J. Mol. Sci. 2021, 22, 12562. https://doi.org/10.3390/ ijms222212562

Academic Editor: Ana

María Díez-Pascual

Received: 12 November 2021 Accepted: 21 November 2021 Published: 22 November 2021

Publisher's Note: MDPI stays neutral with regard to jurisdictional claims in published maps and institutional affiliations.

Copyright: (C) 2021 by the authors Licensee MDPI, Basel, Switzerland. This article is an open access article distributed under the terms and conditions of the Creative Commons Attribution (CC BY) license (https:// creativecommons.org/licenses/by/ $4.0 /)$
Abstract: Herein, we report the green synthesis of silver nanoparticles (OE-Ag NPs) by ecofriendly green processes using biological molecules of Olea europaea leaf extract. Green synthesized OE-Ag NPs were successfully characterized using different spectroscopic techniques. Antibacterial activity of OE-Ag NPs was assessed against four different bacteriological strains using the dilution serial method. The cytotoxic potential was determined against MCF-7 carcinoma cells using MTT assay in terms of cell viability percentage. Antioxidant properties were evaluated in terms of 2,2-diphenyl-1picrylhydrazyl (DPPH) free radical scavenging. Biocompatibility was further examined by incubating the synthesized NPs with hMSC cells for $24 \mathrm{~h}$. The results were demonstrated that synthesized OE-Ag NPs presented excellent $\log _{10}$ reduction in the growth of all the tested bacterial strains, which as statistically equivalent $(p>0.05)$ to the standard antibiotic drug. Moreover, they also demonstrated excellent cytotoxic efficacy against the MCF-7 carcinoma cells compared to plant lead extract and Com-Ag NPs. Green synthesized OE-Ag NPs appeared more biocompatible to hMSC and 293T cells compared to Com-Ag NPs. Excellent biological results of the OE-Ag NPs might be attributed to the synergetic effect of NPs' properties and the adsorbed secondary metabolites of plant leaf extract. Hence, this study suggests that synthesized OE-Ag NPs can be a potential contender for their various biological and nutraceutical applications. Moreover, this study will open a new avenue to produce biocompatible nanoparticles with additional biological functionalities from the plants.

Keywords: Ag NPs; Olea europaea; green synthesis; antioxidant; antimicrobial; cytotoxic

\section{Introduction}

The emergence of drug resistance in different bacteria has become a significant public health problem. Currently, antibiotics have been used as an effective treatment against bacterial exposure owing to their satisfactory outcomes. However, their great use without maintaining prescription policies leads to increased antibiotic resistance in bacteria. Hence, multi-drug resistant (MDR) bacteria were defined as bacteria that acquired resistance to at least one antibiotic from three or more classes of antibiotics and are frequently responsible for infection associated with healthcare settings [1]. Moreover, an infection caused by MDR bacteria has become significantly challenging, especially in developing countries, and has been associated with high morbidity and mortality rates [2]. In addition, it has been estimated that infections by resistant bacteria may rise to 10 million death/year by 2050 more 
than any other causes and like the most global issues [3]. Therefore, the challenge of antibiotic resistance is becoming alarming, and the development of new alternatives antibacterial agents to combat has become an urgent need. Recently, nanotechnology has provided many multi-disciplinary research concepts in the scientific area, which can overcome this challenging situation [4]. This technology has led to the design and fabrication of nanomaterials and nanoparticles with exceptionally high surface area to volume ratio and small size, which determines their physical, chemical, mechanical, optical, electrical, solubility, and stability. Generally, several physical and chemical methods have been intensively used for synthesizing nanoparticles. However, these methods generally involve using a toxic solvent that would pollute the environment and strictly limit the use of NPs in scientific and technical fields. Hence, it is imperative to develop economic alternative processes for nanomaterials synthesizing for future biological applications [5]. Notably, in recent years, nanobiotechnology has been established as a new branch of nanotechnology. This technology combines biological systems with physical and chemical procedures to produce nano-sized particles with specific functions [6]. Hence, biological synthesis or 'green' synthesis of NPs has attracted significant attention due to their cost-effective, environmentally friendly, and resulting biocompatible nanoparticles [7]. Many naturally biological sources, including fungi, bacteria, plants, and algae, have been employed in the biosynthesis of nanoparticles. Although compared to other naturally available biological sources, plants have attracted much attention, and they are more suitable for the biosynthesis of NPs owing to their high stability, easily scalable, readily available, and no particular storage condition required. In typical NPs biosynthesis, plant extracts were used as reducing and stabilizing agents.

Moreover, these extracts are mainly composed of numerous secondary metabolites, such as sugars, polyphenols, flavonoids, and terpenoids. Their oxidation induces the reduction of metal ions and the formation of metallic NPs. Among the different metallic NPs, silver nanoparticles (Ag NPs) have been extensively explored for their exclusive properties (e.g., size and shape depending optical, electrical, and magnetic properties) [8-10]. On the other hand, Ag NPs have been shown to exhibit chemical stability, good conductivity, antibacterial and catalytic activities, as well as a cytotoxic effect on cancer cells [11]. In this regard, phytochemicals and secondary metabolites present in plant extracts can cap and reduce $\mathrm{Ag}^{+}$ions to $\mathrm{Ag}^{0}$ [12]. Therefore, it is suitable for the large-scale synthesis of Ag NPs in a non-aseptic environment.

In this work, we have synthesized Ag NPs using biological molecules of leaf extract of Olea europaea L. Olea europaea L. belongs to the Oleaceae family, is one of the essential fruit trees widely cultivated in the Mediterranean region (approximately $98 \%$ of the world crop) [13]. Olive leaves are agricultural by-products that have attracted growing interest in the scientific and industrial community due to their health benefits and nutritional effects [14]. Hence, Olea europaea leaves were considered promising sources of bioactive compounds, mainly phenolic compounds. The major abundant compounds are Oleuropein and Hydroxytyrosol and other flavonoids, such as Apigenin-7-glucoside, Luteolin-7-glucoside, and Verbascoside $[15,16]$. The isolated bioactive compounds have been found to have antiviral [17], antimicrobial [18], antioxidant [19], anti-inflammatory [20], anticancer [16], antihypertensive [21] and hypoglycemic properties [22]. Thus, in the present research, Ag NPs were synthesized using Olea europaea phytomolecules as a reducing and stabilizing agent. The green synthesized OE-Ag NPs were further evaluated for their different applications, i.e., antioxidant, antibacterial, and anticancer.

\section{Results and Discussion}

\subsection{Characterization}

Olea europaea is a rich source of different biological important secondary metabolites that can be used for the synthesis of biogenic nanoparticles as reducing and capping agents $[23,24]$. Therefore, we have employed the leaf extract of this plant as reducing and capping agents for the synthesis of biogenic silver nanoparticles. Figure 1a presents the possible mechanism for the synthesis of OE-Ag NPs using the plant leaf extract. Polyphe- 
nols and flavonoids present in the leaf extract might be involved in reducing the silver ions to metallic form following the redox reaction. Simultaneously, other secondary metabolites such as alkaloids, terpenoids, saponins present in the leaf extract might readily be stabilized the formed $\mathrm{Ag}^{0}$ by capping and finally converted into silver nanoparticles (OE-Ag NPs). Similar synthesis mechanism was also reported by Hussain et al. [25].
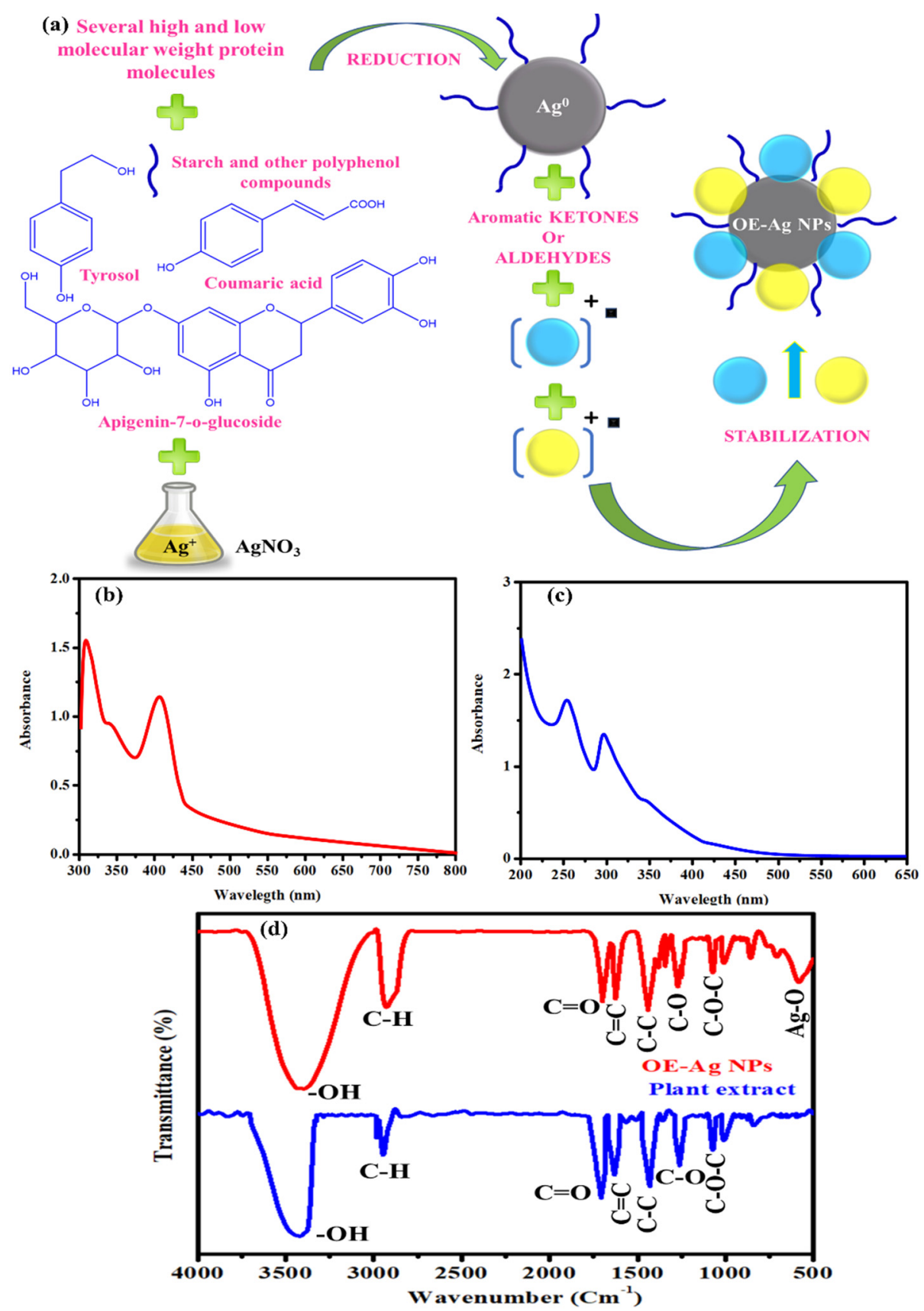

Figure 1. (a) Probable mechanism for the synthesis of OE-Ag NPs. (b,c) UV-Visible spectra of OE-Ag NPs and plant extract respectively. (d) FTIR analysis of plant extract and OE-Ag NPs.

The chemical reaction between the dissolved silver ions and plant leaf extract was examined with a UV-Visible spectrophotometer. UV-Visible analysis revealed that upon reaction completion and formation of OE-Ag NPs, an absorption peak at $410 \mathrm{~nm}$ was observed due to the surface plasmon resonance phenomenon (Figure 1b) [26]. An additional absorption peak at $310 \mathrm{~nm}$ was also observed, which might be due to the adsorbed polyphenols. Literature shows that polyphenols usually produce UV-Visible absorption peaks in the ultra-violet region due to the presence of hydroxyl moieties [27-30]. On the 
other hand, plant leaf extract shows two UV-Visible absorption peaks ( $255 \mathrm{~nm}$ and $290 \mathrm{~nm}$ ) in the ultraviolet region (Figure 1c). A slight blue shift in UV-Visible absorption peaks of plant leaf extract was observed compared to the reported by [31]. This might be attributed to the different phytomolecules present in the leaf extract which depends on the nature of soil and environments in which plant is grow.

FTIR analysis of both plant leaf extract and OE-Ag NPs was carried out further, and their spectra are shown in Figure 1d. FTIR spectra of plant leaf extract showing different IR peaks at $3400 \mathrm{~cm}^{-1}(-\mathrm{OH}), 2920-2880 \mathrm{~cm}^{-1}(\mathrm{C}-\mathrm{H}), 1706 \mathrm{~cm}^{-1}(\mathrm{C}=\mathrm{O}), 1630 \mathrm{~cm}^{-1}$ (aromatic $\mathrm{C}=\mathrm{C}$ ), and several others [31] which indicates the presence of several phytomolecules. On the other hand, OE-Ag NPs are also presented a similar pattern of FTIR peaks with slight shifts in wavenumbers and intensity. Hence, FTIR results corroborated that green synthesized OE-Ag NPs are successfully capped and stabilized with the plant leaf extract's secondary metabolites.

Further, the green synthesized OE-Ag NPs were characterized with XRD. XRD diffraction pattern indicates the sharp, narrow, and intense peaks corroborating the highly crystalline nature of the synthesized NPs (Figure 2a). Four diffraction peaks at $38.60^{\circ}, 44.56^{\circ}$, $64.65^{\circ}$, and $77.65^{\circ}$ were observed, which correspond to crystal planes (111), (200), (220), and (311) respectively [32]. Figure 2b shows the TEM image of the green synthesized OE-Ag NPs. TEM analysis displays that the synthesized NPs are spherical in morphology with uniform distribution. TEM analysis shows that the average size of NPs is $8 \mathrm{~nm}$ (5 to $14 \mathrm{~nm}$ particle size range) (Figure 2c). Figure $2 \mathrm{~d}$ shows the compositional analysis results carried out with EDX. EDX confirms that the synthesized NPs are mainly composed of silver. Besides, the spectra also show different EDX peaks associated with oxygen, nitrogen, and carbon. These peaks might be attributed to the surface adsorbed phytomolecules (alkaloids, polyphenols, flavonoids, etc.) from the plant leaf extract during capping. A consistency was observed in the results of FTIR and EDX analysis. Hence all characterization results confirm the successful fabrication of our desired nanoparticles.

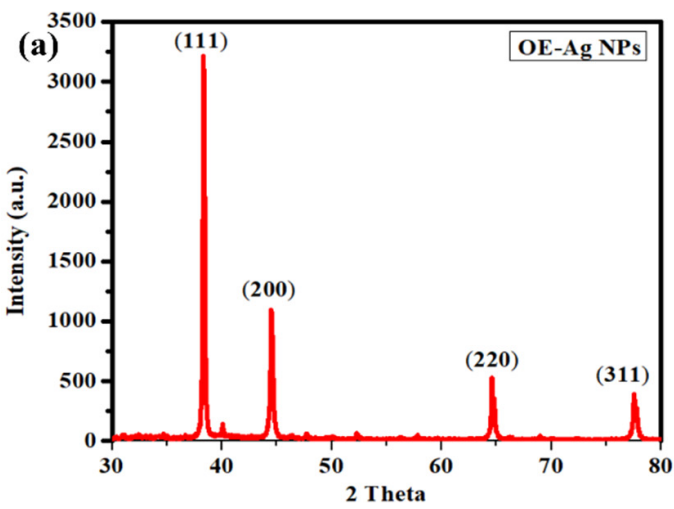

(b)
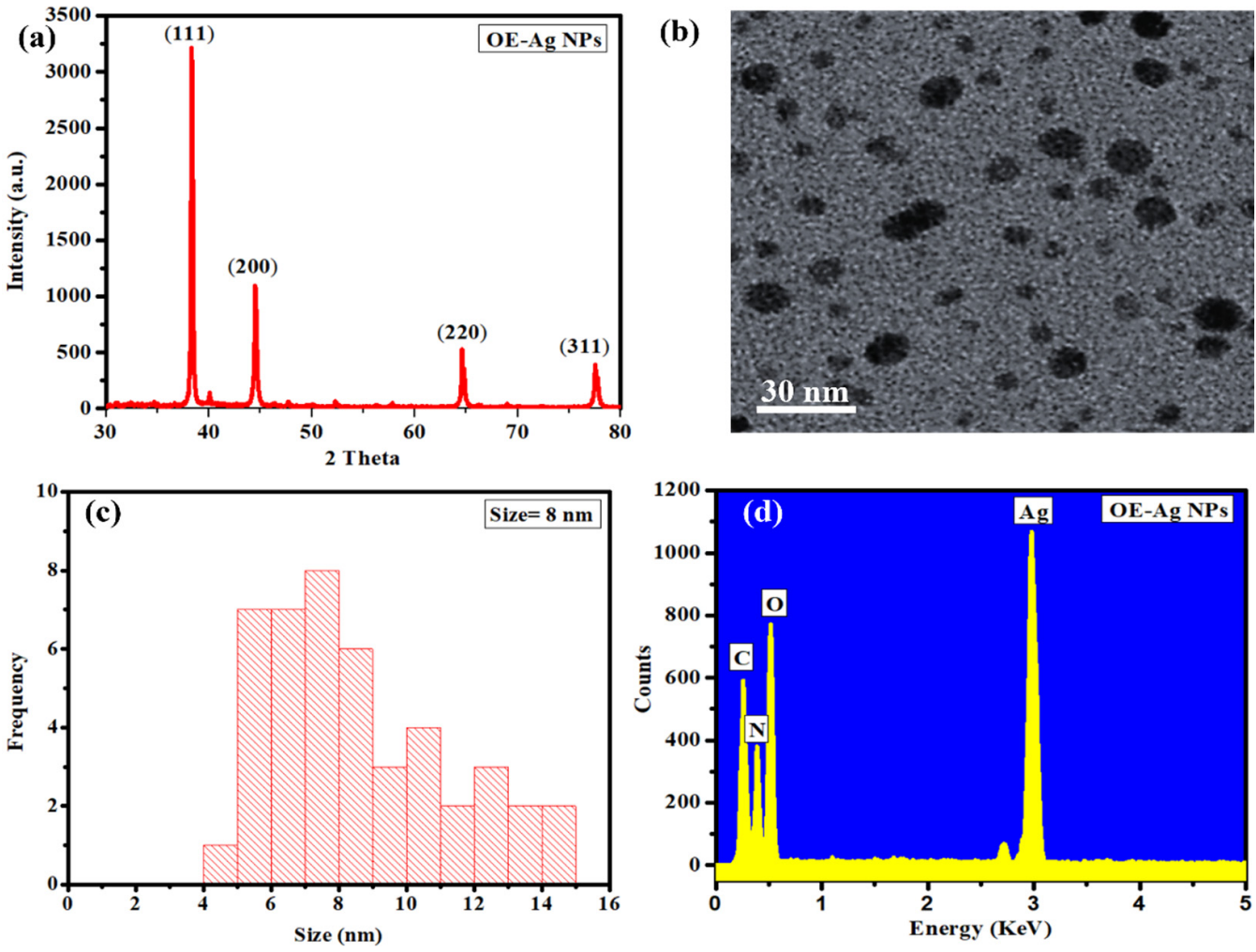

Figure 2. (a) XRD, (b) TEM, (c) Size distribution, and (d) EDX analysis of green synthesized OEAg NPs. 


\subsection{Antibacterial Activity}

Antibacterial activity of green synthesized OE-Ag NPs was assessed against Grampositive and Gram-negative bacterial strains. The results demonstrated the highest antibacterial activity in terms of $\log _{10}$ reductions in bacterial growth with green synthesized OE-Ag NPs compared to a plant extract and Com-Ag NPs (Figure 3). Interestingly, the antibacterial activity presented by green synthesized OE-Ag NPs was comparable $(p>0.05)$ to the standard antibiotic drug. Moreover, plant leaves extract also displayed good antibacterial activity against all the microbial strains. The enhanced antibacterial activity of OE-Ag NPs might be due to the synergistic effect of NPs's physical properties and adsorbed secondary metabolites on their surface from the plant extract, as evident from the results of FTIR and EDX analysis. A similar finding was also reported by $[27,28,30,33-36]$.

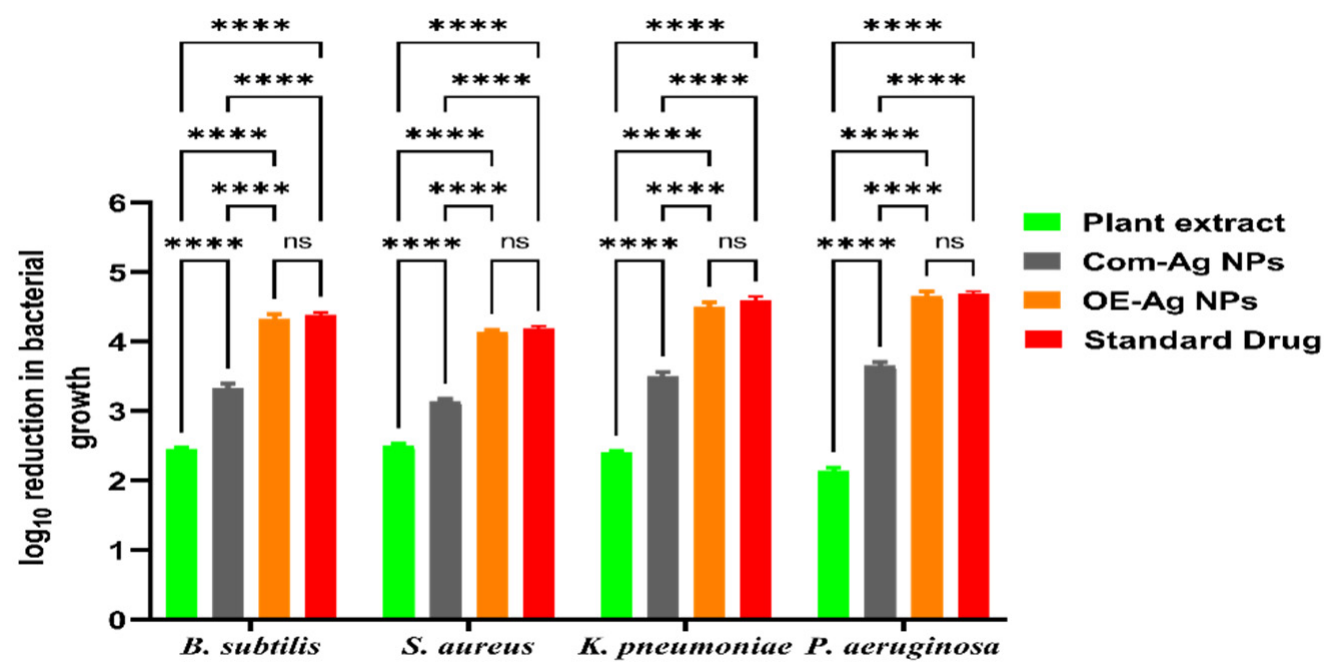

Figure 3. Antibacterial activity of green synthesized OE-Ag NPs in terms of $\log _{10}$ reduction in growth of all tested bacterial strains compared to plant leaves extract, Com-Ag NPs, and standard drug (**** and ns denote $p<0.0005$, and $p>0.05$, respectively).

It has been observed that green synthesized OE-Ag NPs exhibited more efficiency in killing the Gram-negative bacterial strains than that of Gram-positive bacterial strains. This might be attributed to their easy penetration and more electrostatic attraction with surface bounds functional moieties (e.g., sulfur proteins) of the cell wall and cytoplasmic membrane of the Gram-negative bacterial strains compared to Gram-positive. The easy penetration of green synthesized OE-Ag NPs might have occurred because Gram-negative bacterial strains have thinner cell wall than Gram-positive (Figure 4) [37,38]. Moreover, both Gram-positive and Gram-negative bacteria differ in the structure and composition of their cell walls [39] as shown in Figure 4. The cell wall of Gram-positive bacteria comprises of multilayer channels of thick peptidoglycan, lipoteichoic acid and wall teichoic acid. Both lipoteichoic acid and wall teichoic acid are attached to peptidoglycan as well as cell membrane. On the other hand, Gram-negative bacteria cell wall consists of outer/inner membrane layers, thin layer of peptidoglycan, lipopolysaccharides, and gel like periplasm. The lipopolysaccharides are highly negatively charged macromolecules that are only present in outer membrane layers of Gram-negative bacterial strains [38,39]. 


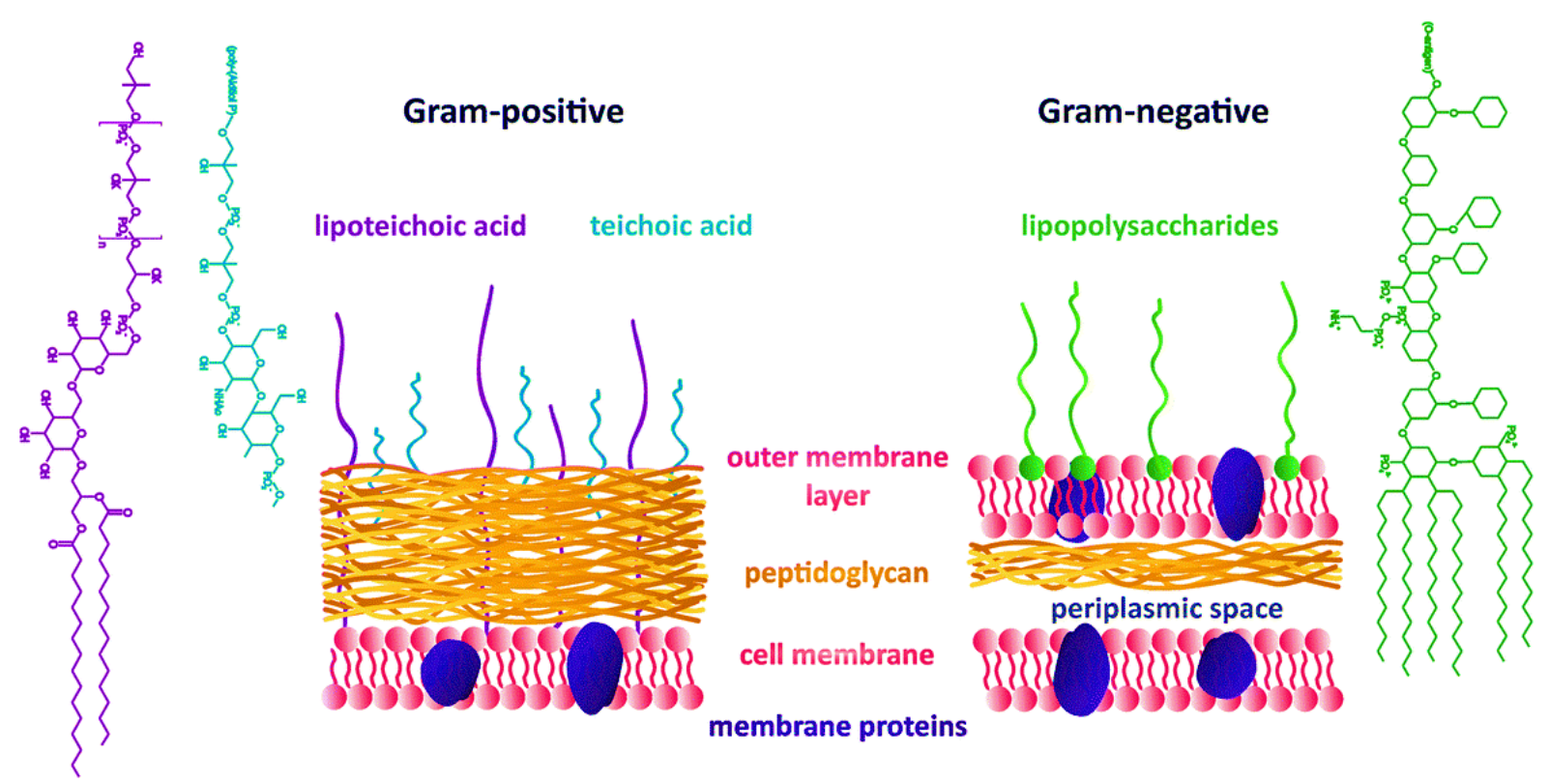

Figure 4. Comparison between the cell wall structure and composition of both Gram-positive and Gram-negative bacterial strains [39].

Antibacterial Mechanism

The antibacterial mechanism of the green synthesized OE-Ag NPs was evaluated further with Live and dead staining assay. Live/dead stating assay was carried out against three bacteria (S. aureus, K. pneumonia, and P. aeruginosa) using a double staining kit (Hoechst 33,342 /PI). Both dyes are used for the differentiation of the live and dead bacteria cells. Hoechst 33,342 is a permanent membrane dye and can stain both live/dead cells upon intercalation with DNA [40]. On the other hand, PI is an impermeant membrane dye that can only penetrate bacteria cells when the cell membrane has been destroyed. Therefore, PI is used for the staining of dead cells. Figure 5 shows that untreated bacterial strains only stained with Hoechst 33,342, indicating that the bacteria cells live, and their cell membrane is intact. On the other hand, treated bacteria demonstrated red fluorescence displaying that their cell membrane has been destroyed by the action of green synthesized OE-Ag NPs. These results revealed that one possible reason behind the antibacterial action of green synthesized OE-Ag NPs is the disruption of bacteria cell membrane integrity.

After confirmation of bacterial cell deaths by physical damage of their cell membrane with the green synthesized OE-Ag NPs, we further hypothesized that bacterial cell death might also be induced by the oxidative stress produced by the reactive oxygen species (ROS) such as hydroxyl radicals $\mathrm{OH}^{\bullet}$, superoxide ions $\mathrm{O}_{2}{ }^{-\bullet}, \mathrm{H}_{2} \mathrm{O}_{2}$, and hydroperoxyl radicals [40]. It has been reported that $\mathrm{Ag}$-based materials and nanoparticles have the ability to generate ROS upon interaction with microbial cells [41-43]. To get more insight into the antibacterial mechanism of the green synthesized OE-Ag NPs, we further performed an intracellular ROS measuring experiment using CellROX ${ }^{\circledR}$ Green staining kit. Figure 6 displayed that no intracellular ROS generation has been taken place in untreated bacteria. However, maximum ROS generation has been observed in all tested bacteria treated with $\mathrm{H}_{2} \mathrm{O}_{2}$. Similar ROS intracellular generation has also experimented with all bacteria treated with green synthesized OE-Ag NPs. These findings further corroborated that the bacteria cell death also resulted from oxidative stress produced by the green synthesized OE-Ag NPs. 


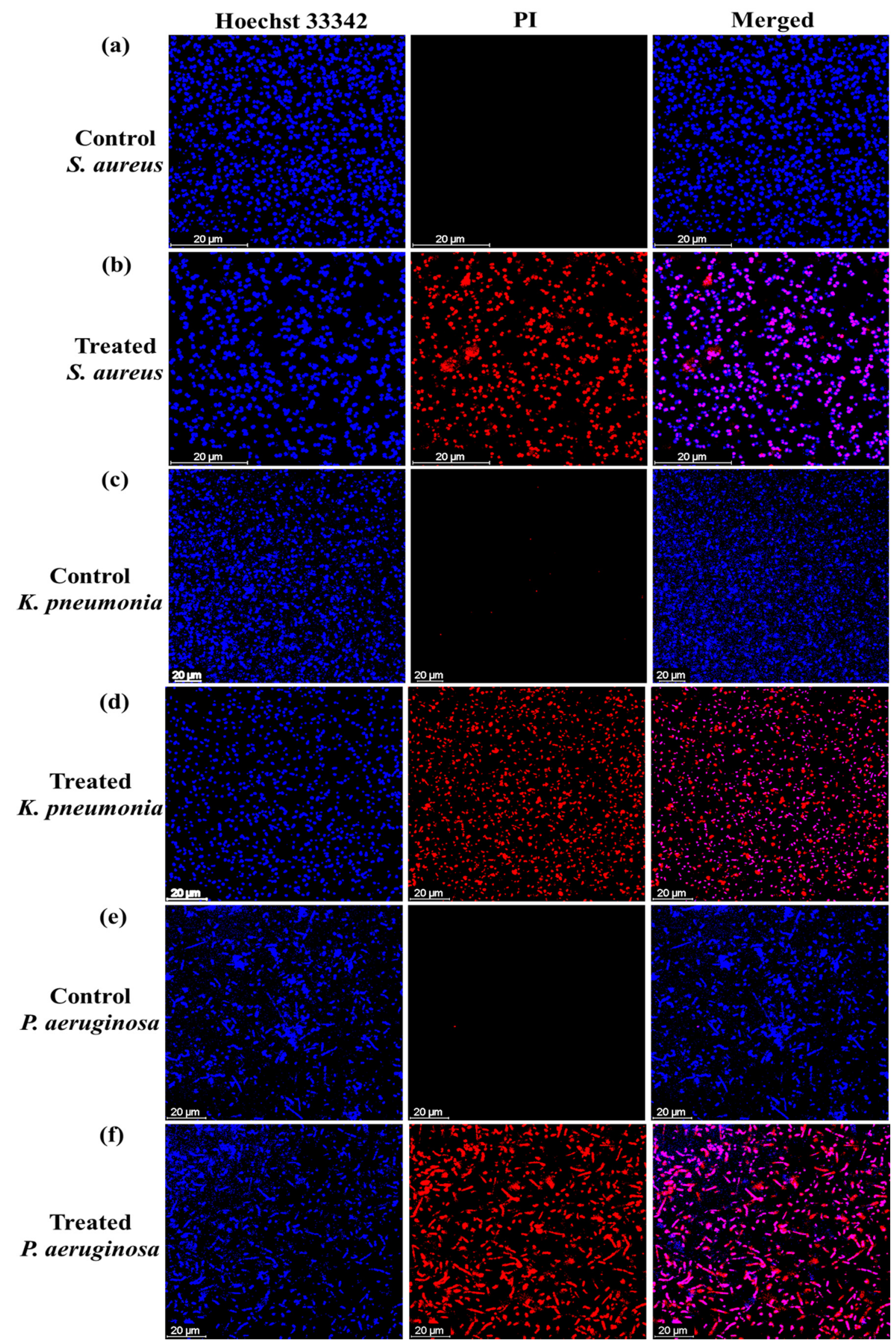

Figure 5. CLSM images of Live/dead bacteria. $(\mathbf{a}, \mathbf{c}, \mathbf{e})$ control and $(\mathbf{b}, \mathbf{d}, \mathbf{f})$ treated bacteria with green synthesized OE-Ag NPs. 


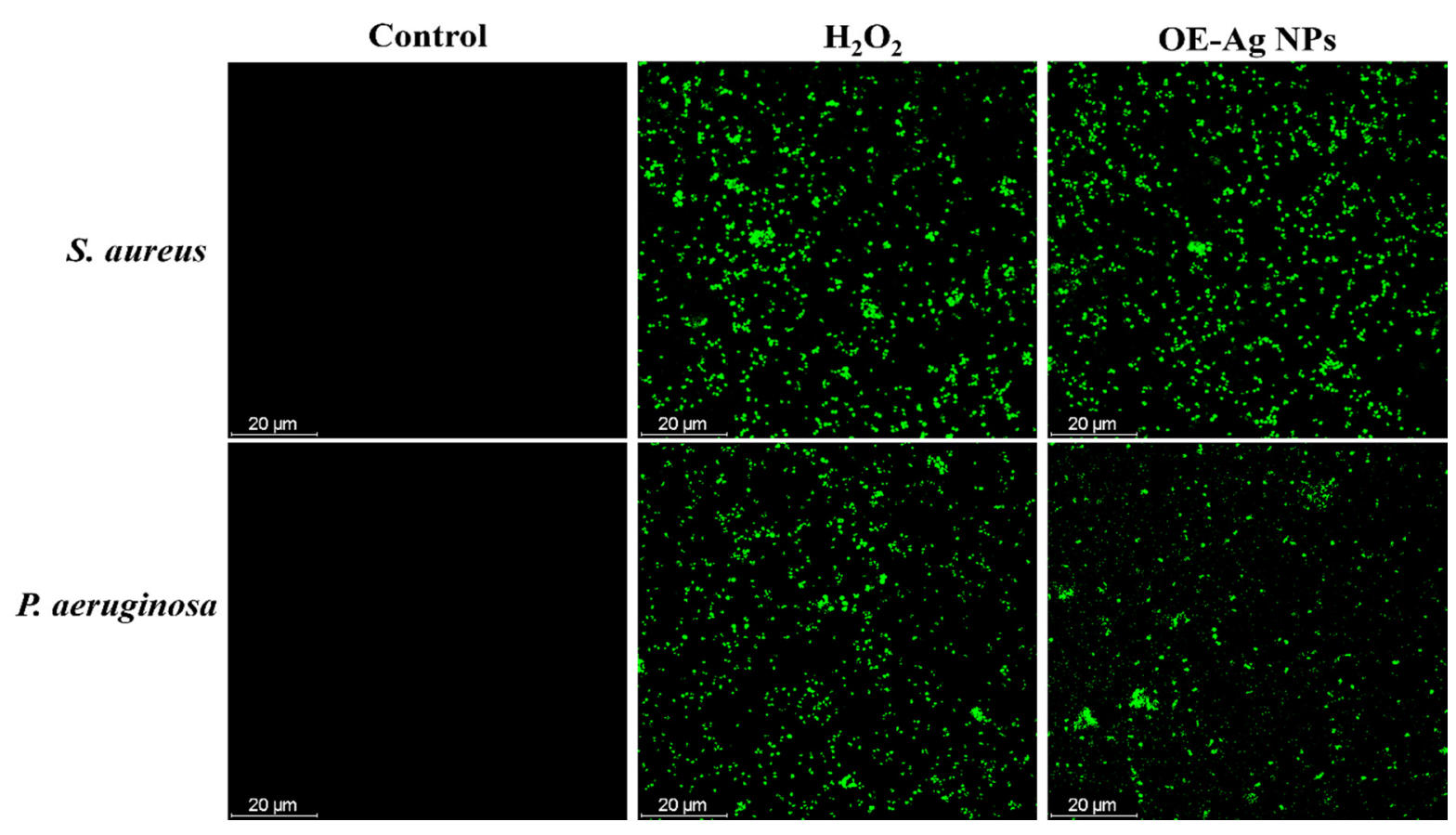

Figure 6. Intracellular ROS generation investigation by CLSM in bacteria (S. aureus and P. aeruginosa) treated with green synthesized OE-Ag NPs in comparison to $\mathrm{H}_{2} \mathrm{O}_{2}$.

After examining the rupture of cell membrane integrity and the generation of intracellular oxidative stress caused by ROS species, we can suggest a mechanism for Bacterial cell death caused by green produced OE-Ag NPs. As a consequence, the OE-Ag NPs exhibited superior antibacterial activity as a result of physical and oxidative degradation, which resulted in the production of various intracellular alterations. (1) The interaction of OE-Ag NPs with cell membrane proteins and other biomacromolecules such as lipopolysaccharides, etc., results in the breakdown of the cell membrane. (2) Disintegration of the cell membrane increased the membrane's permeability for nanoparticle penetration. (3) Membrane permeabilization may also be triggered the leakage of intracellular function. (4) Following their penetration, the OE-Ag NPs may interact with various cellular organelles, causing oxidative stress and further impairing their physiological activities. All of these factors may contribute to the OE-Ag NPs' ability to kill Gram-positive and Gram-negative bacteria.

\subsection{Antioxidant Potential}

The green synthesized OE-Ag NPs' antioxidant potential was evaluated in terms of DPPH free radical scavenging compared to plant leaves extract, Com-Ag NPs, and standard ascorbic acid. The results were displayed the maximum antioxidant activity with green synthesized OE-Ag NPs compared to plant extract and Com-Ag NPs, however comparable to standard ascorbic acid (Figure 7). On the other hand, plant leaf extract significantly scavenged the DPPH free radical and presented good antioxidant potential compared to Com-Ag NPs. The good antioxidant activity of the plant leaves extract might be attributed to the presence of electron-rich secondary metabolites such as phenolics, flavonoids, etc., [44-47]. Secondary metabolites such as phenolics and flavonoids are well-acknowledged to present antioxidant properties [48-50]. In the case of OE-Ag NPs, their enhanced DPPH scavenging ability compared to Com-Ag NPs might also be due to the presence of these secondary metabolites on their surface. Similar findings of enhanced antioxidant activity upon adsorption of these secondary metabolites on the surface of green synthesized NPs and upon metal chelation with phytomolecules compared to alone metal-ligand were also reported by [51-55]. 


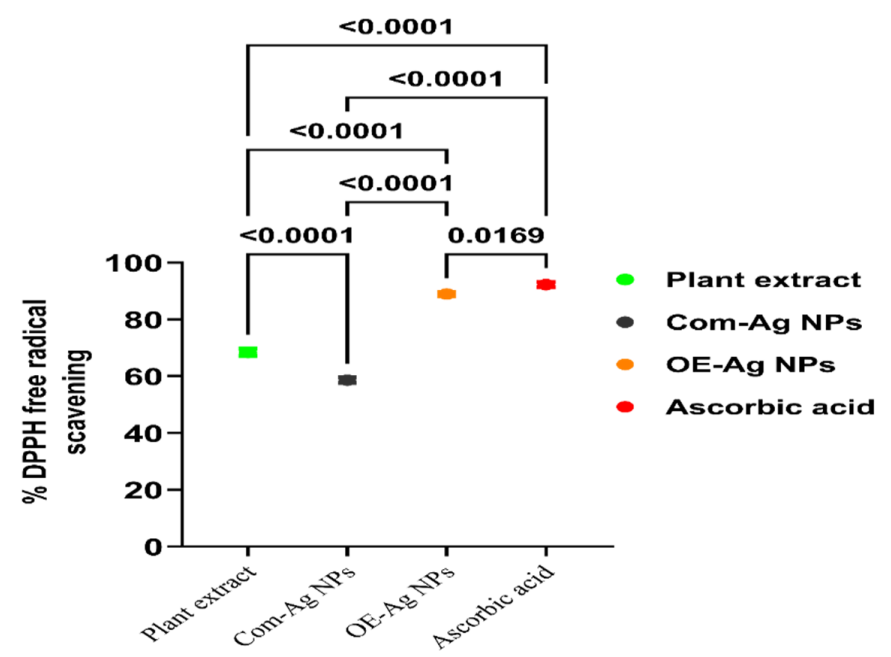

Figure 7. Antioxidant potential evolution in terms of percentage of DPPH free radical scavenging with green synthesized OE-Ag NPs compared to plant leaf extract, Com-Ag NPs, and standard antioxidant (ascorbic acid).

\subsection{Cytotoxic Propensity}

The cytotoxicity propensity of the green synthesized OE-Ag NPs was determined in terms of cell viability percentage of MCF-7 carcinoma cell lines using MTT assay compared to plant extract and Com-Ag NPs. Findings exhibit that the superior cytotoxic effect was induced by the green synthesized OE-Ag NPs than both plant leaf extract and Com-Ag NPs (Figure 8a). On the other hand, Com-Ag NPs presented more cytotoxic efficacy against the MCF-7 carcinoma cells compared to plant leaf extract. It was worthy to note that plant leaf extract also demonstrated good killing efficacy against MCF-7 cells which can be attributed to the presence of cancer killing secondary metabolites (polyphenols, flavonoids, alkaloids, terpenoids, saponins, etc.) [56,57]. On the other hand, enhanced cytotoxic propensity of OE-Ag NPs compared to Com-Ag NPs might be due to the presence of biological active secondary metabolites of plant leaf extract on their surface. Mona et al. has also reported the similar enhanced cytotoxic efficacy of biogenic silver nanoparticles synthesized by lichens [26].
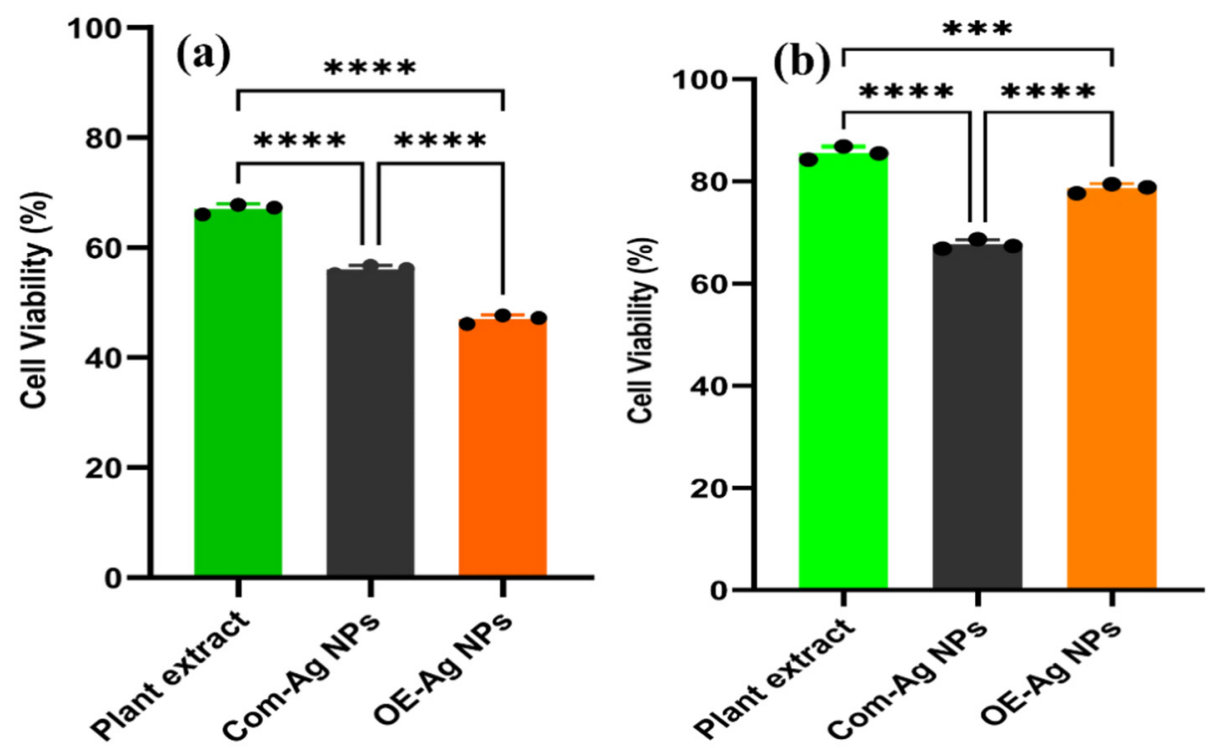

Figure 8. (a) Cytotoxic propensity against MCF-7 carcinoma cells and (b) biocompatibility against hMSC cells after incubation for $24 \mathrm{~h}$ with OE-Ag NPs, plant leaf extract and Com-Ag NPs $\left.{ }^{* * * *} p<0.0001,{ }^{* * *} p<0.0005\right)$. 


\subsection{Biocompatibility Analysis}

Biocompatibility of the nanoparticles is the utmost desire for their application in biological system. Therefore, we further evaluated synthesized OE-Ag NPs for their biocompatibility with normal cell line hMSC using MTT assay compared to plant leaf extract and Com-Ag NPs. The results are presented in Figure 8b. Results were demonstrated that plant leaf extract displayed excellent biocompatibility presenting superior cell viability percentage $(85.51 \%)$. While green synthesized OE-Ag NPs exhibited good biocompatibility with hMSC cell lines and shown $78.66 \%$ cell viability percentage. On the other hand, least biocompatibility was shown by the Com-Ag NPs.

Using the live/dead staining approach, we further evaluated the cytobiocompatibility of the OE-Ag NPs with 293T cell line in comparison to the plant leaf extract Com-Ag NPS. Figure $9 a-d$ illustrates the findings. The results revealed that plant leaf extract and OE-Ag NPs had the least detrimental impact on 293T cells, resulting in fewer cells dying. In comparison, chemically generated Com-Ag NPs were more lethal, and a significant number of cells seemed to be perished (Red). The enhanced cytobiocompatibility of green synthesized OE-Ag NPs with hMSC cells and 293T cells might be resulted because of the existence of biological active and biocompatible secondary metabolites of the plant leaf extract. The similar finding on the biocompatible nature of plant leaf extract and enhanced cytobiocompatibility of the nanoparticles after the inclusion of secondary metabolites on their surface were also reported by $[58,59]$.

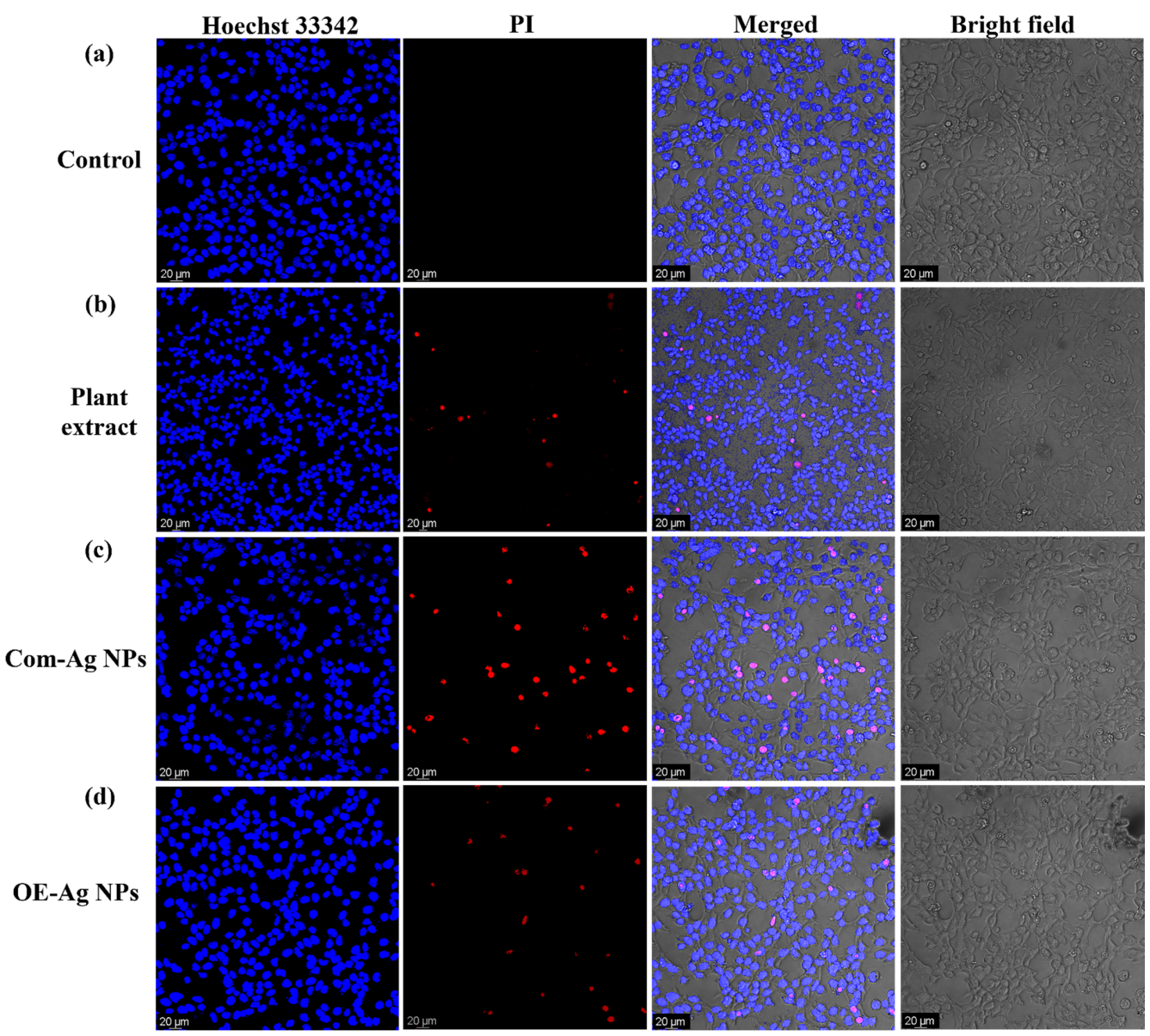

Figure 9. CLSM images of live/dead 293T cells. (a) Control (untreated) and treated with (b) plant extract, (c) Com-Ag NPs, and (d) OE-Ag NPs. 


\section{Materials and Methods}

\subsection{Chemicals and Collection of Plant Materials}

Analytical grade chemicals and chemically synthesized silver nanoparticles (Com-Ag NPs) were purchased from Sigma-Aldrich. Experiments were carried out on leaves of the Chetoui cultivar of Olea europaea L., cultivated in Borj El Amri in the North of Tunisia. Fresh green leaves were collected until the end of olive morphology (February 2019). Olea europaea leaves were identified and authenticated by Professor Fathi Ben Amar at the olive institute of Sfax, Tunisia.

\subsection{Plant Extract Preparation and OE-Ag NPs Synthesis}

Fresh leaves of Olea europaea were washed with deionized water (DI) to remove dust particles, plankton, and insects, and then dried under shady at room temperature $\left(25-30^{\circ} \mathrm{C}\right)$. The dried leaves were milled into powder using a commercial grinder. The plant leaves powder was stored in glass bottles for future use. The preparation of plant extract and synthesis of OE-Ag NPs was carried out following the procedure reported by [30]. Ten $g$ of the ground leaves powder of Olea europaea was added to $100 \mathrm{~mL}$ of DI water. Then, the aqueous mixture was heated to boil with rigorous stirring for $5 \mathrm{~min}$. The boiled mixture was filtered with filter paper to get a yellowish-colored extract. Then, the leaves extract was used as a reducing and capping agent to convert silver salt to its metallic form. A total of $1 \mathrm{mM}$ of $\mathrm{AgNO}_{3}$ was added to $25 \mathrm{~mL}$ of leaves extract of Olea europaea. Afterward, the mixture was heated at $80^{\circ} \mathrm{C}$ for $65 \mathrm{~min}$ with constant stirring to obtain a dark brown dispersion of OE-Ag NPs. After centrifugation for $15 \mathrm{~min}$ at 15,000 rpm, the obtained OE-Ag NPs were washed with DI water three times and dried in an oven at $70^{\circ} \mathrm{C}$.

\subsection{Characterization of $\mathrm{OE}-\mathrm{Ag} N P \mathrm{~s}$}

The green synthesis OE-Ag NPs were characterized using different spectroscopic techniques. X-ray Diffraction (XRD) was performed using Bruker $\mathrm{D}_{2}$ PHASER with LYNXEYE XE-T detector diffractometer (Haidian, Beijing, China) operating at $40 \mathrm{kV}$ and $30 \mathrm{~mA}$ with $\mathrm{Cu} \mathrm{K} \alpha$ radiation $\left(\mathrm{k}=1.54056 \mathrm{~A}^{\circ}\right)$ to test the crystallinity and purity of OE-Ag NPs. Energydispersive X-ray spectroscopy using Thermo Fisher Scientific Ultradry (Madison, WI, USA) was performed to determine the elemental composition of the green-synthesized OE-Ag NPs. A transmission electron microscope (TEM) (Jeol, 5910 LV, Tokyo, Japan) was carried out to determine the morphology of the synthesized Ag NPs. Fourier Transform Infra-Red spectra (FTIR) (Bruker, Germany. Model: Vertex 70) analysis was performed to determine whether phytomolecules of plant leaves extract were involved or not in the green synthesis of OE-Ag NPs. UV-visible analysis was carried out using a spectrophotometer (Shimadzu 1700, Columbia, MD, USA).

\subsection{Antioxidant Activity}

Antioxidant activity of the green synthesis OE-Ag NPs was determined by using a DPPH free radical scavenging assay [5]. In a typical experiment, DPPH solution $(0.1 \mathrm{mM})$ in ethanol was mixed with different concentrations $(500 \mu \mathrm{g} / \mathrm{mL}$ ) of each sample (OE-Ag NPs, plant extract, Com-Ag NPs, and standard) that were prepared separately. Then, the reaction mixtures were stirred for $10 \mathrm{~min}$ and kept in the dark at room temperature for $1 \mathrm{~h}$. After incubation, the absorbance was measured with a UV-Visible spectrophotometer at $517 \mathrm{~nm}$. The percentage scavenging activity was calculated using the following formula:

$$
\% \text { DPPH free radical scavenging }=\left[\left(A_{b}-A_{s}\right) / A_{b}\right] \times 100,
$$

where $A_{s}$ is the absorbance of the sample and $A_{b}$ is the blank absorbance (only DPPH solution).

\subsection{Antibacterial Activity}

The synthesized OE-Ag NPs were scrutinized for their antibacterial activity against two Gram-negative bacterial strains [Pseudomonas aeruginosa (ATCC ${ }^{\circledR} 27853 \mathrm{TM}$ ) and Kleb- 
siella pneumonia $\left(\operatorname{ATCC}^{\circledR}\right.$ 13,883)] and two Gram-positive bacterial strains [Staphylococcus aureus $\left(\right.$ ATCC $^{\circledR} 15,564$ ) and Bacillus subtilis (ATCC ${ }^{\circledR}$ 6051)] using the serial dilution method as described by [60]. In general, the strains of bacteria $\left(5 \times 10^{5} \mathrm{CFU} / \mathrm{mL}\right)$ were seeded onto separate blood agar plates and then cultured for $24 \mathrm{~h}$ at $37^{\circ} \mathrm{C}$. After several bacterium colonies were grown on the plates, they were diluted with phosphate buffer saline (PBS). Their cell density was maintained to $1 \times 10^{7}$ colony forming units (CFU) per mL. Following that, $10 \mu \mathrm{L}$ of each bacterial culture was separately added to the wells of a 24-well microtiter plate with $1.0 \mathrm{~mL}$ of Mueller-Hinton broth (MHB). For each well, the final concentration of each bacterium was $1 \times 10^{5} \mathrm{CFU} / \mathrm{mL}$. A $50 \mu \mathrm{L}$ of each sample solution at $250 \mu \mathrm{g} / \mathrm{mL}$ concentration was then transferred to separate wells and incubated at $37^{\circ} \mathrm{C}$ for $24 \mathrm{~h}$. The bacterial species were then counted in the wells using the serial dilution plate counting method. The antibacterial propensity was expressed in the form of $\log _{10}$ reduction in bacterial growth using the following formula:

$$
\log _{10} \text { reduction }=\log _{10}\left(\mathrm{CFU}_{\mathrm{BI}}\right)-\log _{10}(\mathrm{CFU} \mathrm{AI}) \text {, }
$$

where $\mathrm{CFU}_{\mathrm{BI}}$ and $\mathrm{CFU}_{\mathrm{AI}}$ are the $\mathrm{CFU}$ of bacterial strains before and after $24 \mathrm{~h}$ of incubation, respectively, with the treatment of sample solutions. Standard antibiotic drug used in this study was Cefradine.

\subsection{Live/Dead Bacterial Staining Assay}

Live and dead bacterial staining assay was carried out using a confocal laser scanning microscope (CLSM, FV-1200, Olympus, Tokyo, Japan) to confirm the antibacterial activity of green synthesized OE-Ag NPs. The assay was performed following the methods reported by Choi et al. [61]. Briefly, two nucleic dyes, Hoechst 33,342 (membrane-permeant) and propidium iodide (PI; membrane-impermeant), were used for staining the live (green) and dead (red) bacteria, respectively. Each bacterium was cultured in nutrient broth in an orbital shaker for $24 \mathrm{~h}$ at $37^{\circ} \mathrm{C}$ to reach the stationary phase, which was consists of approximately $10^{5}-10^{6}$ colony forming units (CFU) per ml. After incubation, each bacteria strain was inoculated into sterilized cover glass coated with poly-L-lysine in a 24-well plate and then incubated for $1 \mathrm{~h}$ for bacterial cells attached to the cover glass. The suspended bacterial cells were then discarded, and each cover glass was gently rinsed three times with a saline solution. For the treatment, each bacterium cells on the cover glass were incubated with green synthesized OE-Ag NPs $(250 \mu \mathrm{g} / \mathrm{mL})$ and then incubated for $24 \mathrm{~h}$ at $37^{\circ} \mathrm{C}$. Bacteria cells on cover glass were then stained with an alive and dead bacterial viability kit in accordance with the manufacturer's recommendations. Dead and live bacterial cells were analyzed with CLSM using an excitation wavelength of $493 \mathrm{~nm}$ and $350 \mathrm{~nm}$ for PI and Hoechst 33,342 and an emission wavelength of $636 \mathrm{~nm}$ and $461 \mathrm{~nm}$ for PI and Hoechst 33,342, respectively. We only considered green synthesized OE-Ag NPs for live/dead staining assay as they presented excellent antibacterial properties in terms of $\log _{10}$ reductions.

\subsection{Intracellular ROS Generation Investigations}

The CellROX ${ }^{\circledR}$ Green staining was further used to examine the death of bacterial species caused by intracellular ROS production. In brief, bacterial species (Staphylococcus aureus and Pseudomonas aeruginosa) at $1 \times 10^{7} \mathrm{CFU} / \mathrm{mL}$ with $70 \mu \mathrm{L}$ of produced OE-Ag NPs at a concentration of $250 \mu \mathrm{g} / \mathrm{mL}$ and incubating at $37^{\circ} \mathrm{C}$ for $24 \mathrm{~h}$. Following that, the microbial cells were treated for an additional $30 \mathrm{~min}$ at $37^{\circ} \mathrm{C}$ with CellROX ${ }^{\circledR}$ Green $(5 \mu \mathrm{m})$. Following that, CLSM was utilized to acquire CLSM images at $485 \mathrm{~nm}$ absorption and $520 \mathrm{~nm}$ emission wavelengths. To assess microbial cells' ability to generate reactive oxygen species (ROS), the results of cells treated with NPs were compared to those treated with $1 \mathrm{~mm} \mathrm{H} \mathrm{O}_{2}$ (positive control) and untreated cells (negative control). 


\subsection{Anticancer Activity}

The OE-Ag NPs were tested for their anticancer activity against MCF-7 (breast cancer cells) by MTT (3-(4, 5-dimethylthiazol-2-yl)-2, 5-diphenyltetrazolium bromide) colorimetric assay [30]. The MCF-7 carcinomatous cells were kept in Dulbecco's Modified Eagle's Medium (DMEM) in a humidified atmosphere comprising $5 \% \mathrm{CO}_{2}$ and $95 \%$ air at $37^{\circ} \mathrm{C}$. To get the cell confluency $\left(5 \times 10^{8}\right.$ cells / well), MCF-7 cells were cultured in a 96-microtiter plate containing $100 \mu \mathrm{L}$ of DMEM for $24 \mathrm{~h}$ at $37^{\circ} \mathrm{C}$ in $5 \% \mathrm{CO}_{2}$. Different concentrations $(1,5,10,15,30,60$, and $120 \mu \mathrm{g} / \mathrm{mL})$ of green synthesized OE-Ag NPs were prepared in cell culture media and then mixed with cancer cells, and the plate was further incubated for $24 \mathrm{~h}$ at $37^{\circ} \mathrm{C}$. Cells without OE-Ag NPs were served as a negative control, and cells with the standard drug (doxorubicin) were served as a positive control. Afterward, the plate was centrifuged to remove the supernatant and subsequently washed with phosphate buffer saline solution. A total of $15 \mu \mathrm{L}$ of MTT reagent at the concentration of $0.5 \mathrm{mg} / \mathrm{mL}$ was added to each well, and the plate was then incubated for $4 \mathrm{~h}$ at $37^{\circ} \mathrm{C}$. After incubation, $150 \mu \mathrm{L}$ of DMSO were added to each well to solubilize the formazan crystals and kept on a shaker for 10 to $15 \mathrm{~min}$. The absorption of the formazan product was determined using a spectrophotometer at $570 \mathrm{~nm}$. The percentage of cell viability was calculated using the following formula:

$$
\text { Cell viability }=\left[\mathrm{OD}_{\text {sample }} / \mathrm{OD}_{\text {control }}\right] \times 100 \text {, }
$$

\subsection{Biocompatibility Analysis}

The similar experiment was repeated as stated in Section 3.8. The only difference was cell lines. In this study, we used hMSC line.

Then, using the fluorescent staining approach, we employed a live/dead double staining kit to determine the viability of 293T cell line. The procedure was repeated until cancer cells were treated with different samples $(10 \mu \mathrm{L}$ at a concentration of $120 \mu \mathrm{g} / \mathrm{mL})$ and incubated after treatment. After that, each well was incubated with the staining solution $(4 \mathrm{~g} / \mathrm{mL})$ for $20 \mathrm{~min}$ at $37^{\circ} \mathrm{C}$. The images were taken using confocal laser scanning microscopy (CLSM) $(535 / 617 \mathrm{~nm}$ and $361 / 497 \mathrm{~nm}$ excitation/emission wavelengths for PI and Hoechst 33,342, respectively).

\subsection{Statistical Analysis}

All biological assays were performed at three replicates, and results are presented in Mean \pm SD. The significance level at $p<0.05$ between the results was determined by applying One-way and two-way ANOVA.

\section{Conclusions}

Herein, we successfully reported the green synthesis of silver nanoparticles (OEAg NPs) by ecofriendly green processes using biological molecules of Olea europaea leaf extract. Green synthesized OE-Ag NPs were successfully characterized using different spectroscopic techniques. The results were demonstrated that synthesized OE-Ag NPs presented excellent $\log _{10}$ reduction in the growth of all the tested bacterial strains, which as statistically equivalent $(p>0.05)$ to the standard antibiotic drug. Moreover, they also demonstrated excellent cytotoxic efficacy against the MCF-7 carcinoma cells compared to plant lead extract and Com-Ag NPs. Green synthesized OE-Ag NPs appeared more biocompatible to $293 \mathrm{~T}$ and hMSC cells compared to Com-Ag NPs. Excellent biological results of the OE-Ag NPs might be attributed to the synergetic effect of NPs' properties and the adsorbed secondary metabolites of plant leaf extract. Hence, this study suggests that synthesized OE-Ag NPs can be a potential contender for their various biological and nutraceutical applications. More study must be carried out to determine the dosedependent biocompatibility in vitro as well as in vivo. Moreover, this study will open a new avenue to produce biocompatible nanoparticles with additional biological functionalities from the plants. 
Author Contributions: Conceptualization, H.S. and S.A.K.; methodology, H.S. and S.A.K.; software, H.S.; validation, H.S. and S.A.K.; formal analysis, H.S.; investigation, H.S.; resources, H.S.; data curation, H.S., S.A.K. and I.A.; writing-original draft preparation, H.S., S.A.K. and I.A.; writingreview and editing, S.A.K., I.A., A.A.A., A.H.H. and A.E.A.-S.; visualization, H.S., S.A.K., I.A., A.A.A., A.H.H. and A.E.A.-S.; supervision, S.A.K.; project administration, S.A.K.; funding acquisition, A.A.A., A.H.H. and A.E.A.-S. All authors have read and agreed to the published version of the manuscript.

Funding: This research was funded by King Saud University, Riyadh, Saudi Arabia, grant number RG-1435-065. The APC was funded by RG-1435-065.

Institutional Review Board Statement: Not applicable.

Informed Consent Statement: Not applicable.

Data Availability Statement: The data are not publicly available.

Acknowledgments: The authors are very thankful to Fathi Ben Amar, from the olive institute of Sfax, Tunisia, for providing the leaves of Olea europaea used for this work. The authors extend their appreciation to the Deanship of Scientific Research at King Saud University for funding this work through research group no (RG-1435-065).

Conflicts of Interest: The authors declare no conflict of interest.

\section{References}

1. Magiorakos, A.P.; Srinivasan, A.; Carey, R.B.; Carmeli, Y.; Falagas, M.E.; Giske, C.G.; Harbarth, S.; Hindler, J.F.; Kahlmeter, G.; Olsson-Liljequist, B.; et al. Multidrug-resistant, extensively drug resistant and pan drug-resistant bacteria: An international expert proposal for interim standard definitions for acquired resistance. Clin. Microbiol. Infect 2012, 18, 268-281. [CrossRef]

2. Singh, N.; Manchanda, V. Control of multidrug-resistant gram-negative bacteria in low-and middle-income countries-high impact interventions without much resources. Clin. Microbiol. Infect 2017, 23, 216-218. [CrossRef] [PubMed]

3. Islam, S.; Aldstadt, J.; Aga, D. Global antimicrobial resistance: A complex and dire threat with few definite answers. Trop. Med. Int. Health 2019, 24, 658-662. [CrossRef] [PubMed]

4. Nasrollahzadeh, M.; Sajadi, S.M.; Sajjadi, M.; Issaabadi, Z. An Introduction to Nanotechnology. Interface Sci. Technol. 2019, 28, $1-27$.

5. Khan, S.A.; Noreen, F.; Kanwal, S.; Iqbal, A.; Hussain, G. Green synthesis of ZnO and Cu-doped ZnO nanoparticles from leaf extracts of Abutilon indicum, Clerodendrum infortunatum, Clerodendrum inerme and investigation of their biological and photocatalytic activities. Mater. Sci. Eng. C 2018, 82, 46-59. [CrossRef]

6. Foldbjerg, R.; Jiang, X.; Miclăuş, T.; Chen, C.; Autrup, H.; Beer, C. Silver nanoparticles-wolves in sheep's clothing? Toxicol. Res. 2015, 4, 563-575. [CrossRef]

7. Kumari, S.; Kumari, P.; Panda, P.K.; Patel, P.; Jha, E.; Mallick, M.A.; Suar, M.; Verma, S.K. Biocompatible biogenic silver nanoparticles interact with caspases on an atomic level to elicit apoptosis. Nanomedicine 2020, 15, 2119-2132.

8. Kaliamurthi, S.; Selvaraj, G.; Cakmak, Z.E.; Cakmak, T. Production and characterization of spherical thermostable silver nanoparticles from Spirulina platensis (Cyanophyceae). Phycologia 2016, 55, 568-576. [CrossRef]

9. Satyavani, K.; Ramanathan, T.; Gurudeeban, S. Plant mediated synthesis of biomedical silver nanoparticles by using leaf extract of Citrullus colocynthis. Res. J. Nanosci. Nanotechnol. 2011, 1, 95-101.

10. Caro, C.; Castillo, P.M.; Klippstein, R.; Pozo, D.; Zaderenko, A.P. Silver nanoparticles: Sensing and imaging applications. In Silver Nanoparticles; Perez, D.P., Ed.; InTech: Rijeka, Croatia, 2010; Volume 95, pp. 201-224.

11. Wijnhoven, S.W.P.; Peijnenburg, W.J.G.M.; Herberts, C.A.; Hagens, W.I.; Oomen, A.G.; Heugens, E.H.W.; Roszek, B.; Bisschops, J.; Gosens, I.; Van de Meent, D.; et al. Nano-silver: A review of available data and knowledge gaps in human and environmental risk assessment. Nanotoxicology 2009, 3, 109-138. [CrossRef]

12. Das, G.; Patra, J.K.; Shin, H.S. Biosynthesis, and potential effect of fern mediated biocompatible silver nanoparticles by cytotoxicity, antidiabetic, antioxidant and antibacterial, studies. Mater. Sci. Eng. C 2020, 114, 111011. [CrossRef] [PubMed]

13. Tabera, J.; Guinda, A.; Ruiz-Rodriguez, A.; Senorans, J.F.; Ibanez, E.; Albi, T.; Reglero, G. Countercurrent supercritical fluid extraction and fractionation of high-added-value compounds from a hexane extract of olive leaves. J. Agric. Food Chem. 2004, 52, 4774-4779. [CrossRef]

14. de Bock, M.; Thorstensen, E.B.; Derraik, J.G.; Henderson, H.V.; Hofman, P.L.; Cutfield, W.S. Human absorption and metabolism of oleuropein and hydroxytyrosol ingested as olive (Olea europaea L.) leaf extract. Mol. Nutr. Food Res. 2013, 57, $2079-2085$. [CrossRef]

15. Briante, R.; Patumi, M.; Terenziani, S.; Bismuto, E.; Febbraio, F.; Nucci, R. Olea europaea L. leaf extract and derivatives: Antioxidant properties. J. Agric. Food Chem. 2002, 50, 4934-4940. [CrossRef] [PubMed]

16. Goulas, V.; Exarchou, V.; Troganis, A.N.; Psomiadou, E.; Fotsis, T.; Briasoulis, E.; Gerothanassis, I.P. Phytochemicals in olive-leaf extracts and their antiproliferative activity against cancer and endothelial cells. Mol. Nutr. Food Res. 2009, 53, 600-608. [CrossRef] 
17. Micol, V.; Caturla, N.; Pérez-Fons, L.; Mas, V.; Pérez, L.; Estepa, A. The olive leaf extract exhibits antiviral activity against viral haemorrhagic septicaemia rhabdovirus (VHSV). Antiviral Res. 2005, 66, 129-136. [CrossRef] [PubMed]

18. Pereira, A.P.; Ferreira, I.C.F.R.; Marcelino, F.; Valentão, P.; Andrade, P.B.; Seabra, R.; Estevinho, L.; Bento, A.; Pereira, J.A. Phenolic compounds and antimicrobial activity of olive (Olea europaea L. Cv. Cobrancs,osa) leaves. Molecules 2007, 12, 1153-1162. [CrossRef] [PubMed]

19. Bouaziz, M.; Sayadi, S. Isolation and evaluation of antioxidants from leaves of a Tunisian cultivar olive tree. Eur. J. Lipid. Sci. Tech. 2005, 107, 497-504. [CrossRef]

20. Visioli, F.; Bellosta, S.; Galli, C. Oleuropein, the bitter principle of olives, enhances nitric oxide production by mouse macrophages. Life Sci. 1998, 62, 541-546. [CrossRef]

21. Somova, L.I.; Shode, F.O.; Ramnanan, P.; Nadar, A. Antihypertensive, antiatherosclerotic and antioxidant activity of triterpenoids isolated from Olea europaea, subspecies africana leaves. J. Ethnopharmacol. 2003, 84, 299-305. [CrossRef]

22. Wainstein, J.; Ganz, T.; Boaz, M.; Dayan, Y.B.; Dolev, E.; Kerem, Z.; Madar, Z. Olive leaf extract as a hypoglycemic agent in both human diabetic subjects and in rats. J. Med. Food 2012, 15, 605-610. [CrossRef] [PubMed]

23. Rashidipour, M.; Heydari, R. Biosynthesis of silver nanoparticles using extract of olive leaf: Synthesis and in vitro cytotoxic effect on MCF-7 cells. J. Nanostruct. Chem. 2014, 4, 112. [CrossRef]

24. Khalil, M.M.H.; Ismail, E.H.; El-Baghdady, K.Z.; Mohamed, D. Green synthesis of silver nanoparticles using olive leaf extract and its antibacterial activity. Arab. J. Chem. 2014, 7, 1131-1139. [CrossRef]

25. Hussain, A.; Alajmi, M.F.; Khan, M.A.; Pervez, S.A.; Ahmed, F.; Amir, S.; Husain, F.M.; Khan, M.S.; Shaik, G.M.; Hassan, I.; et al. Biosynthesized Silver Nanoparticle (AgNP) From Pandanus odorifer Leaf Extract Exhibits Anti-metastasis and Anti-biofilm Potentials. Front. Microbiol. 2019, 10, 8. [CrossRef]

26. Alqahtani, M.A.; al Othman, M.R.; Mohammed, A.E. Bio Fabrication of Silver Nanoparticles with Antibacterial and Cytotoxic Abilities Using Lichens. Sci. Rep. 2020, 10, 16781. [CrossRef]

27. Parthiban, E.; Manivannan, N.; Ramanibai, R.; Mathivanan, N. Green Synthesis of Silver-Nanoparticles from Annona Reticulata Leaves Aqueous Extract and Its Mosquito Larvicidal and Anti-Microbial Activity on Human Pathogens. Biotechnol. Rep. 2018, 20, e00297. [CrossRef]

28. Ajitha, B.; Ashok Kumar Reddy, Y.; Sreedhara Reddy, P. Green Synthesis and Characterization of Silver Nanoparticles Using Lantana Camara Leaf Extract. Mater. Sci. Eng. C 2015, 49, 373-381. [CrossRef]

29. Kasprzak, M.M.; Erxleben, A.; Ochocki, J. Properties and Applications of Flavonoid Metal Complexes. RSC Adv. 2015, 5, 45853-45877. [CrossRef]

30. Khan, S.A.; Shahid, S.; Lee, C.-S.S. Green Synthesis of Gold and Silver Nanoparticles Using Leaf Extract of Clerodendrum Inerme; Characterization, Antimicrobial, and Antioxidant Activities. Biomolecules 2020, 10, 835. [CrossRef]

31. Matteis, V.; de Rizzello, L.; Ingrosso, C.; Liatsi-Douvitsa, E.; Giorgi, M.L.; de Matteis, G.; de Rinaldi, R. Cultivar-Dependent Anticancer and Antibacterial Properties of Silver Nanoparticles Synthesized Using Leaves of Different Olea Europaea Trees Nanomaterials 2019, 9, 1544. [CrossRef]

32. Anandalakshmi, K.; Venugobal, J.; Ramasamy, V. Characterization of Silver Nanoparticles by Green Synthesis Method Using Pedalium Murex Leaf Extract and Their Antibacterial Activity. Appl. Nanosci. 2015, 6, 399-408. [CrossRef]

33. Khan, M.; Shaik, M.R.; Adil, S.F.; Khan, S.T.; Al-Warthan, A.; Siddiqui, M.R.H.; Tahir, M.N.; Tremel, W. Plant Extracts as Green Reductants for the Synthesis of Silver Nanoparticles: Lessons from Chemical Synthesis. Dalton. Trans. 2018, 47, 11988-12010. [CrossRef] [PubMed]

34. Roy, A.; Bulut, O.; Some, S.; Mandal, A.K.; Yilmaz, M.D. Green Synthesis of Silver Nanoparticles: Biomolecule-Nanoparticle Organizations Targeting Antimicrobial Activity. RSC Adv. 2019, 9, 2673-2702. [CrossRef]

35. Hirpara, D.G.; Gajera, H.P. Green Synthesis and Antifungal Mechanism of Silver Nanoparticles Derived from Chitin- Induced Exometabolites of Trichoderma Interfusant. Appl. Organomet. Chem. 2020, 34, e5407. [CrossRef]

36. Anandan, M.; Poorani, G.; Boomi, P.; Varunkumar, K.; Anand, K.; Chuturgoon, A.A. Green Synthesis of Anisotropic Silver Nanoparticles from the Aqueous Leaf Extract of Dodonaea Viscosa with Their Antibacterial and Anticancer Activities. Process. Biochem. 2019, 80, 80-88. [CrossRef]

37. Yin, I.X.; Zhang, J.; Zhao, I.S.; Mei, M.L.; Li, Q.; Chu, C.H. The Antibacterial Mechanism of Silver Nanoparticles and Its Application in Dentistry. Int. J. Nanomed. 2020, 15, 2555. [CrossRef] [PubMed]

38. Slavin, Y.N.; Asnis, J.; Häfeli, U.O.; Bach, H. Metal Nanoparticles: Understanding the Mechanisms behind Antibacterial Activity. J. Nanobiotechnol. 2017, 15, 65. [CrossRef] [PubMed]

39. Pajerski, W.; Ochonska, D.; Brzychczy-Wloch, M.; Indyka, P.; Jarosz, M.; Golda-Cepa, M.; Sojka, Z.; Kotarba, A. Attachment Efficiency of Gold Nanoparticles by Gram-Positive and Gram-Negative Bacterial Strains Governed by Surface Charges. J. Nanopart. Res. 2019, 21, 186. [CrossRef]

40. Ramalingam, B.; Parandhaman, T.; Das, S.K. Antibacterial Effects of Biosynthesized Silver Nanoparticles on Surface Ultrastructure and Nanomechanical Properties of Gram-Negative Bacteria Viz. Escherichia Coli and Pseudomonas Aeruginosa. ACS Appl. Mater. Interfaces 2016, 8, 4963-4976. [CrossRef] [PubMed]

41. Kim, J.S.; Kuk, E.; Yu, K.N.; Kim, J.H.; Park, S.J.; Lee, H.J.; Kim, S.H.; Park, Y.K.; Park, Y.H.; Hwang, C.Y.; et al. Antimicrobial Effects of Silver Nanoparticles. Nanomed. Nanotechnol. Biol. Med. 2007, 3, 95-101. [CrossRef] 
42. Chernousova, S.; Epple, M. Silver as Antibacterial Agent: Ion, Nanoparticle, and Metal. Angew. Chem. Int. Ed. 2013, 52, $1636-1653$. [CrossRef] [PubMed]

43. Carlson, C.; Hussain, S.M.; Schrand, A.M.; Braydich-Stolle, L.K.; Hess, K.L.; Jones, R.L.; Schlager, J.J. Unique Cellular Interaction of Silver Nanoparticles: Size-Dependent Generation of Reactive Oxygen Species. J. Phys. Chem. B 2008, 112, 13608-13619. [CrossRef] [PubMed]

44. Rizwan, K.; Khan, S.A.; Ahmad, I.; Rasool, N.; Ibrahim, M.; Zubair, M.; Jaafar, H.Z.E.; Manea, R. A Comprehensive Review on Chemical and Pharmacological Potential of Viola Betonicifolia: A Plant with Multiple Benefits. Molecules 2019, 24, 3138. [CrossRef]

45. Lfitat, A.; Zejli, H.; Bousraf, F.Z.; Bousselham, A.; el Atki, Y.; Gourch, A.; Lyoussi, B.; Abdellaoui, A. Comparative Assessment of Total Phenolics Content and in Vitro Antioxidant Capacity Variations of Macerated Leaf Extracts of Olea Europaea L. and Argania Spinosa (L.) Skeels. Mater. Today Proc. 2021, 45, 7271-7277. [CrossRef]

46. Ghorbel, A.; Wedel, S.; Kallel, I.; Cavinato, M.; Sakavitsi, M.E.; Fakhfakh, J.; Halabalaki, M.; Jansen-Dürr, P.; Allouche, N. Extraction Yield Optimization of Oleaster (Olea Europaea Var. Sylvestris) Fruits Using Response Surface Methodology, LC/MS Profiling and Evaluation of Its Effects on Antioxidant Activity and Autophagy in HFF Cells. J. Food Meas. Charact. 2021, 15, 4946-4959. [CrossRef]

47. Lins, P.G.; Marina Piccoli Pugine, S.; Scatolini, A.M.; de Melo, M.P. In Vitro Antioxidant Activity of Olive Leaf Extract (Olea Europaea L.) and Its Protective Effect on Oxidative Damage in Human Erythrocytes. Heliyon 2018, 4, e00805. [CrossRef] [PubMed]

48. Bagchi, T.B.; Chattopadhyay, K.; Sivashankari, M.; Roy, S.; Kumar, A.; Biswas, T.; Pal, S. Effect of Different Processing Technologies on Phenolic Acids, Flavonoids and Other Antioxidants Content in Pigmented Rice. J. Cereal. Sci. 2021, 100, 103263. [CrossRef]

49. Hernández, I.; Alegre, L.; van Breusegem, F.; Munné-Bosch, S. How Relevant Are Flavonoids as Antioxidants in Plants? Trends Plant Sci. 2009, 14, 125-132. [CrossRef] [PubMed]

50. Pietta, P.G. Flavonoids as Antioxidants. J. Nat. Prod. 2000, 63, 1035-1042. [CrossRef] [PubMed]

51. Kharat, S.N.; Mendhulkar, V.D. Synthesis, Characterization and Studies on Antioxidant Activity of Silver Nanoparticles Using Elephantopus Scaber Leaf Extract. Mater. Sci. Eng. C 2016, 62, 719-724. [CrossRef] [PubMed]

52. Samsonowicz, M.; Regulska, E.; Kalinowska, M. Hydroxyflavone Metal Complexes-Molecular Structure, Antioxidant Activity and Biological Effects. Chem.-Biol. Interact 2017, 273, 245-256. [CrossRef]

53. Marslin, G.; Siram, K.; Maqbool, Q.; Selvakesavan, R.K.; Kruszka, D.; Kachlicki, P.; Franklin, G. Secondary Metabolites in the Green Synthesis of Metallic Nanoparticles. Materials 2018, 11, 940. [CrossRef]

54. Khan, A.U.; Khan, A.U.; Li, B.; Mahnashi, M.H.; Alyami, B.A.; Alqahtani, Y.S.; Alqarni, A.O.; Khan, Z.U.H.; Ullah, S.; Wasim, M.; et al. Biosynthesis of Silver Capped Magnesium Oxide Nanocomposite Using Olea Cuspidata Leaf Extract and Their Photocatalytic, Antioxidant and Antibacterial Activity. Photodiagnosis Photodyn. Ther. 2021, 33, 102153. [CrossRef] [PubMed]

55. Mahendiran, D.; Subash, G.; Arumai Selvan, D.; Rehana, D.; Senthil Kumar, R.; Kalilur Rahiman, A. Biosynthesis of Zinc Oxide Nanoparticles Using Plant Extracts of Aloe Vera and Hibiscus Sabdariffa: Phytochemical, Antibacterial, Antioxidant and Anti-Proliferative Studies. BioNanoScience 2017, 7, 530-545. [CrossRef]

56. Antoniou, C.; Hull, J. The Anti-Cancer Effect of Olea Europaea L. Products: A Review. Curr. Nutr. Rep. 2021, 10, 99-124. [CrossRef]

57. Essafi Rhouma, H.; Trabelsi, N.; Chimento, A.; Benincasa, C.; Tamaalli, A.; Perri, E.; Zarrouk, M.; Pezzi, V. Olea Europaea L. Flowers as a New Promising Anticancer Natural Product: Phenolic Composition, Antiproliferative Activity and Apoptosis Induction. Nat. Prod. Res. 2019, 5, 1-4. [CrossRef] [PubMed]

58. Zaïri, A.; Nouir, S.; Zarrouk, A.; Haddad, H.; Khélifa, A.; Achour, L. Phytochemical Profile, Cytotoxic, Antioxidant, and Allelopathic Potentials of Aqueous Leaf Extracts of Olea Europaea. Food Sci. Nutr. 2020, 8, 4805-4813. [CrossRef] [PubMed]

59. Rezaeian, M.; Afjoul, H.; Shamloo, A.; Maleki, A.; Afjoul, N. Green Synthesis of Silica Nanoparticles from Olive Residue and Investigation of Their Anticancer Potential. Nanomedicine 2021, 16, 1581-1593. [CrossRef] [PubMed]

60. Shahid, S.; Fatima, U.; Sajjad, R.; Khan, S.A. Bioinspired nanotheranostic agent: Zinc oxide; green synthesis and biomedical potential. Dig. J. Nanomater. Biostruct. 2019, 14, 1023-1031.

61. Choi, K.H.; Nam, K.C.; Lee, S.Y.; Cho, G.; Jung, J.S.; Kim, H.J.; Park, B.J. Antioxidant Potential and Antibacterial Efficiency of Caffeic Acid-Functionalized ZnO Nanoparticles. Nanomaterials 2017, 7, 148. [CrossRef] [PubMed] 